\title{
CARACTERIZAÇÃO DA VARIAÇÃO DO LENÇOL FREÁTICO NAS ÁREAS DE MINERAÇÃO DE "XISTO” (FOLHELHO PIROBETUMINOSO) EM SÃO MATEUS DO SUL-PR
}

ALDO MAFFEI PIETRO FERNANDES

DISSERTAÇÃO DE MESTRADO - Programa de Pós-Graduação em Geologia - UFPR

DATA DE DEFESA: 30/07/99

O estudo objetivou, principalmente, definir a abrangência do impacto exercido pela mineração do folhelho pirobetuminoso ou "xisto", no rebaixamento do lençol freático em terrenos naturais, na área da PETROBRÁS-SIX, em São Mateus do Sul, Estado do Paraná. Foram também analisadas as alterações que ocorrem no quimismo da água e a nova posição do nível do lençol freático nos terrenos reabilitados, após a mineração. A lavra é efetuada a céu aberto, ocorrendo portanto uma drástica alteração na paisagem local, onde a cava atinge cerca de 30 metros de profundidade. A jazida do minério apresenta duas camadas distintas de folhelho, separadas por uma camada intermediária considerada estéril. Denominadas de camada superior e camada inferior, as duas apresentam, respectivamente, espessuras médias de 6 e 3 metros e teores de óleo de 6 a $8 \%$ e 10 a $12 \%$. Para possibilitar o estudo do lençol freático nos terrenos naturais, ainda não minerados, diversos piezômetros foram implantados. O monitoramento do nível de água nos piezômetros foi realizado diariamente pela PETROBRÁS-SIX, no período de 1995 a 1996, simultaneamente ao avanço e aproximação da mina. Os dados assim obtidos foram fornecidos mensalmente, acompanhados das informações de pluviometria e temperatura. Com estes dados foram elaborados mapas de potenciometria máxima, média e mínima para a área de estudo, assim como gráficos relacionando o nível de água nos piezômetros com a precipitação, com a distância à frente de lavra e com as detonações. A análise dos resultados mostra que a principal causa das oscilações do lençol freático são as variações sazonais. A mina também exerce influência no abaixamento do nível de água, porém isto somente ocorre quando a frente de lavra aproxima-se dos piezômetros a uma distância inferior a 70 metros. Aos 65 metros de distância, observa-se uma inversão de fluxo na direção da mina. Por ocasião de uma detonação, foi constatada a secagem dos piezômetros mais próximos. Ao ser estudado o freático nas áreas reabilitadas, foram utilizados dados obtidos de piezômetros instalados na antiga Mina UPI e em terrenos mais recentes. Nestes locais, o abaixamento do nível de água é irreversível e o lençol assume uma nova posição, próxima ao piso da antiga mina. Para a verificação das características físico-químicas das águas do sistema SIX, amostras foram coletadas e analisadas nos laboratórios da PETROBRÁS-SIX e UFPR. Dado o conteúdo piritoso do folhelho, as águas que ocorrem na área já apresentam naturalmente um certo grau de acidez. Porém, nas áreas reabilitadas esta característica é ampliada, somando-se ao excessivo teor de sais dissolvidos, porque o fracionamento do material retortado que preenche a cava da mina favorece os processos de dissolução e lixiviação. Assim, dois grupos distintos podem ser caracterizados: um representado pelas águas que percolam as áreas reabilitadas e o outro representado pelas águas das áreas ainda não atingidas pela mineração. O primeiro grupo, com alta salinidade, apresenta natureza cálcica. O segundo grupo, com baixa salinidade, apresenta características sódio-magnesianas. 